\title{
Students' perceptions and behavior toward on-campus foodservice operations
}

\author{
Ruth Annette Smith and Andrea White-McNeil \\ Bob Billingslea School of Hospitality Management, \\ Bethune-Cookman University, Daytona Beach, Florida, USA, and \\ Faizan Ali \\ College of Hospitality and Tourism Leadership, \\ University of South Florida - Sarasota-Manatee, Sarasota, Florida, USA
}

\begin{abstract}
Purpose - The purpose of this paper is to determine the students' perceptions of an on-campus foodservice operation at an identified historically black college and university (HBCU) and its effect on their satisfaction and dining frequency.

Design/methodology/approach - A survey of 685 students was conducted to collect data. Partial least squares based structural equation modeling is used to test the proposed structural model with SmartPLS 3.0. Findings - Results confirm that quality of food, ambience, value for money, food and beverage options and service quality have a positively significant impact on students' overall satisfaction with the on-campus foodservice operation and dining frequency. As such, all the hypotheses are supported.

Research limitations/implications - These findings indicate that on-campus foodservice operators should focus on quality of food, ambience, value for money, food and beverage options and service quality to achieve student satisfaction. This in turn could positively impact the institution's reputation, student retention and the marketability of the institution to future students.

Originality/value - This study would help on-campus foodservice operators to better understand the impact of the various elements of foodservice experience which will lead to students' overall satisfaction and dining frequency, particularly in a HBCU setting.
\end{abstract}

Keywords Satisfaction, Student perceptions, HBCU, Historically black colleges and universities, On-campus food service

Paper type Research paper

\section{Introduction}

University foodservice is one of the largest segments of the foodservice industry globally, with an increasing number of the captive college-student market using the foodservice outlets on campus during their studies (Garg, 2014). In 2014, there were $11.8 \mathrm{~m}$ college and university students under age 25 and $8.1 \mathrm{~m}$ students 25 years old and over - a significant increase over previous decades (US Department of Education, National Center for Education Statistics, 2016). Consequently, university students' perceptions of their on-campus foodservice operation are crucial to influencing their levels of satisfaction, dining frequency and overall college experience (Hall, 2014). With the reported enrollment growth, economic conditions and the captive nature of the college-student foodservice market, it has been

(C) Ruth Annette Smith, Andrea White-McNeil and Faizan Ali. Published in International Hospitality Review. Published by Emerald Publishing Limited. This article is published under the Creative Commons Attribution (CC BY 4.0) licence. Anyone may reproduce, distribute, translate and create derivative works of this article (for both commercial and non-commercial purposes), subject to full attribution to the original publication and authors. The full terms of this licence may be seen at http://creativecommons.org/licences/by/4.0/legalcode

This work is funded by The Research Work Innovation Seed Grant, Bethune-Cookman University, Office of the Provost.
On-campus

Received 26 June 2019 Revised 22 October 2019 Accepted 5 December 2019 
IHR

34,1

increasingly challenging to achieve student satisfaction with on-campus foodservices among diverse student groups, particularly on campuses with restricted foodservice options. Moreover, foodservice providers face many challenges serving the Millennial students that are culturally diverse, fickle, sophisticated, experienced in their dining habits and often confined to campus, thus making their needs more complex (Choi et al., 2013; Joung et al., 2014). The College and University Consumer Trend Report (Technomic, 2011) indicates that only 28 percent of American students surveyed were satisfied with the healthy menu options on campus, and only 34 percent expressed overall satisfaction with their on-campus dining facilities, ultimately impacting their dining frequency. Therefore, on-campus foodservice providers will need to recognize their consumers' behavior and work toward satisfying them to successfully attract users to the dining services.

While a growing number of studies have examined quality of service, quality of food, value for money, food options and ambience in university foodservices (Joung et al., 2016; Tudin et al., 2010; Dollah et al., 2012), there has been sparse research about students' perceptions of on-campus foodservice operations in historically black colleges and universities (HBCU). There is also lack of research on perceptions of on-campus dining service providers across different types of students, i.e. residents and commuters. This lack of research creates a gap in the body of knowledge of student opinions and behaviors of the on-campus foodservice in HBCUs. HBCUs are defined as institutions established prior to 1964, with the sole purpose of educating African-Americans (Gasman, 2013). According to the National Center for Education Statistics, in 2017 there were 102 HBCUs located in 19 states, the District of Columbia and the US Virgin Islands. Nichols and Evans-Bell (2017) indicated that HBCUs serve 15 percent of the African-American higher education student populace. Research indicates African-Americans choose HBCUs for the history, legacy, racial pride, traditions, academic support and a sense of belongingness unique to such institutions (Brown and Ricard, 2007; Fletcher, 2014). As well, Chickering and Reisser's (1993) psychosocial theory of development posited a positive identity and self-awareness can be enhanced by an understanding of, and involvement in the cultural environment and heritage to which they belong. Thus, since the establishment of the first HBCU in 1837, the institutions have a commitment within the curricular, co-curricular and extra-curricular environments to foster the history and legacy of the African-American ethnicity (Palmer and Gasman, 2008). HBCUs usually accommodate high percentages of residential students of the dominant culture and one way in which African-Americans display their culture is with food. Hall (2014) emphasized that the cultural backgrounds of residential students influence their perceptions of the quality of meal experience in on-campus foodservice operations. Since many residential university campuses provide limited or no alternative source of meals other than the on-campus foodservices (Hall, 2014), it can be argued that the students' perceptions of on-campus foodservice operations are crucial their overall satisfaction and dining frequency at these establishments. Considering these issues, the purpose of this research was to investigate the students' satisfaction with on-campus foodservice facilities and their dining frequency from an HBCU perspective, specifically in relation to the quality of food, ambience, value, food and beverage options, and service and if this satisfaction leads to their dining frequency. In addition, this study also tests these relationships across two distinct groups of students, i.e. students with a residential meal plan and students without a residential meal plan.

\section{Research context}

This research was conducted at an HBCU in southern USA, a coeducational, residential institution that provides on-campus housing for 3,000 students. The university is one of 102 accredited HBCUs in the USA and one of 51 private nonprofit institutions (IPEDS, 2016). In fall 2017, the religious-affiliated institution enrolled 4,143 students of which 96 percent 
were full time students, 80 percent were black or African-Americans, 12 percent race unknown and 3 percent Hispanic, and 2636 residential. The foodservice is provided by an internationally known contract foodservice company which operates three on-site locations, one being the main dining hall facility. The dining hall is cafeteria style described as an eclectic mix of all-you-can-eat options. The menu, however, is limited. Breakfast consists of limited meat, starch and fruit options, whereas lunch and dinner consist of a salad bar, pizza/pasta and/or southern-style food entree and a desert bar. Occasionally, there is variety in the form of an international cuisine option. The menu items rarely differ between lunch and dinner, and the menu is on a two-month cycle. The additional outlets feature made-to-order salads, wraps and sub-sandwiches. Operation of the main dining hall occurs during designated breakfast, lunch and dinner hours while the other outlets are open for lunch and through the dinner hours.

Students are expected to purchase meal plans - blocks of meals for the semester. Residential students are required to purchase blocks which cover 24 meals per week, while commuter students purchase blocks of 75 or 100 meals to be used up in the academic year. Thus, from the perspective of the foodservice operator, meals are prepaid, and operations are confined by that budget.

Given the characteristics and profile of the institution's captive student market, the foodservices provided and the limitations outlined, it was critical to know how the students perceived the elements of service and operations attributes such as quality of food, ambience, price, food and beverage options, and overall service of the foodservice providers and if this satisfaction translates into their dining frequency. This study provides valuable insights into the attributes that are perceived important, and the students' level of satisfaction of these attributes. The on-campus foodservice providers can use the results of this study to form predictors of future customer demands of their operations.

\section{Literature review}

Globally, empirical studies have explored levels of satisfaction with on-campus foodservice operations including services provided by contracted companies, restricted foodservice operations and foodservices that include multiple locations and options on site (Joung et al., 2016; Tudin et al., 2010). In these studies, several attributes including food quality, service quality, atmosphere, cleanliness, location, food and beverage options, convenience, price and value were examined to determine levels of satisfaction. Hu et al. (2009) indicated that customer satisfaction evolves over a series of different experiences and defined it as an intellectual or emotional reaction that develops in response to a single or extended set of service encounters. How individuals perceive quality as it pertains to food and service reflect their opinions of the overall satisfaction with the food or service and the discrepancy between their expectations and their perceptions of the food or service (Joung et al., 2016). While perceptions of quality are subject to individual experiences, they are not necessarily evaluated objectively, because of the complex and intangible characteristics associated with the concept of perception (Kwun, 2011). Thus, it is necessary to review previous research that discussed these critical characteristics that impact customers' perceptions and ultimately their levels of satisfaction with foodservice operations within higher education institutions.

\section{Customer satisfaction}

Customer satisfaction can generate repeat business and lack of it could result in frustration, negative publicity and loss of business. Both satisfaction and dissatisfaction influence customers' attitudes and behavior toward foodservice operations which ultimately lead to the customers' perceptions about foodservice operations, how much they are prepared to spend, and their frequency in dining out (Ali and Ryu, 2015; Lam and Heung, 1998; 
IHR

34,1

Oz et al., 2016). Ali and Ryu's (2015) study of student's foodservice experience and its influences on satisfaction, frequency of dining and expenditures concluded that customer experience significantly affects their level of satisfaction and behavior, especially regarding how much they spend and how often they dine out. Many researchers consider customer satisfaction as an important indicator of determining both outcome and quality and have established a connection between tangible and intangible foodservice attributes and customer satisfaction. For example, Lam and Heung (1998) conducted a study in Hong Kong that assessed customers' expectations of, and satisfaction with foodservice at different universities. Their analysis from the 292 completed surveys indicated that the quality of the food, price, cleanliness and types of food offerings were key attributes in determining customers' satisfaction levels. A conclusion was drawn that a positive correlation was evident between customers' satisfaction levels and perceptions of the foodservice providers' performance. Conversely, Othman et al. (2013) examined factors that influenced customer satisfaction of institutional foodservice at 25 universities in a region in Malaysia and found that customers had negative perceptions of the facilities due to unmet expectations particularly with product quality, value to customer and technological application. Considering the findings of previous studies, Williams (2013) identified five trends that university foodservice providers need to adopt to ensure the entire campus dining experience yield customers' satisfaction. These include:

(1) Operating on students' time by expanding opening hours.

(2) Offering high-end food courts on campuses - with high-quality meal experiences as well as seating, flooring and lighting selected to create the right atmosphere.

(3) Encourage and follow feedback to keep students satisfied.

(4) Tracking the population and use the data in the decision-making process.

(5) Providing the right mix of foodservice offerings. Each campus has a unique culture, philosophy and design, so every dining experience must be unique.

In another study, El-Said and Fathy (2015) surveyed 543 students at the University of Alexandria in Egypt to determine their satisfaction with different dimensions of food and beverage services including quality of food and beverage, service quality, and price and value. The study revealed that students' satisfaction with different service attributes was below average, and that all service attributes had a significant and positive impact on student satisfaction overall.

More recently, Joung et al. (2016) surveyed 346 participants at a public university in the southwest USA to determine the effects of gender, perceived quality and perceived value of campus foodservice on customer satisfaction. The results of the study suggested that perceived quality and perceived value had substantial effects on customer satisfaction. Additionally, the results indicated that gender had a significant role on the relationship between perceived quality and perceived value. The findings of Joung et al.'s (2016) study supported a previous study by Kwun's (2011) study which found that service quality, product quality, menu and facility have positive effects on perceived value and customer satisfaction.

\section{Food and beverage quality}

Previous studies showed the significant role of food and beverage quality in determining student satisfaction. Imram (1999) identified the various attributes of food and beverage quality as aroma, flavor, texture, temperature, shape, color, gloss, freshness, taste, smell, appearance and consistency. In assessing customer satisfaction levels with various attributes of food and beverage quality, Yen-Soon et al. (2004) surveyed 276 customers at a food court at 
Oklahoma State University. They concluded that food quality overall was the most important attribute of customer satisfaction while generating positive word-of-mouth referrals of the foodservice providers. $\mathrm{Ng}$ (2005) proposed that overall food quality attributes such as taste, freshness and appearance play an integral role in attaining or surpassing customers' satisfaction and their intent to return than other factors such as convenience, price, cleanliness and value. In another study, Andaleeb and Caskey (2007) found that students at Pennsylvania State University perceived food quality as one of the three most crucial elements that explained their satisfaction with the foodservice on campus. Other factors included price of food, staff conduct, speed of service, atmosphere and cleanliness. Likewise, Kim et al. (2009) used the DINESERV measuring scale to measure customers' perception of a university dining facility. Findings of the study showed that food quality was the most important predictor of satisfaction followed by service quality, price/value, convenience and atmosphere. It was evident in the study that all these factors were influential factors of positive comments about the cafeteria and possible repeat business. Therefore, based on the evidence provided in the literature there is relationship between the quality of food and beverage, customers' overall satisfaction and subsequent behaviors.

\section{Service quality}

Several researchers have developed measurement tools to evaluate and improve service quality in foodservice operations. For example, Parasuraman et al. (1985, 1988) developed SERVQUAL which measures the gap between what customers expect from a service entity and the service they perceive to have been provided with specific reference to five dimensions: reliability, assurance, responsiveness, empathy and tangibles. Similarly, Stevens et al. (1995) proposed an instrument called DINESERV, which measures customers' perception of service quality in the foodservice industry, using the five dimensions of service in the SEVQUAL model. DINESERV has been used to conduct surveys and account for the changes in customers' perceptions as the results of changes in normative expectations and of service quality delivered (Heung et al., 2000). Despite the extensive use of SERVQUAL and DINESERVE service quality measurement scales, they have been found to be insufficient in comprehensively capturing the service quality concept in the restaurant industry (Raajpoot, 2002; Ryu and Jang, 2008). According to Parasuraman et al. $(1988,1991)$, different customers will critic the same service differently based upon their diverse individual characteristics since service quality has been found to be multi-dimensional. Considering service quality is defined within the context of customers' expectations and perceptions of the service offered (Y1lmaz, 2008), the same service that is perceived as low or mediocre quality by one customer may be viewed as high by another customer. This means, service quality is dependent on how the customers perceive the service based upon their individual experiences.

Previous researchers found the quality of service to be an important influential factor in determining customer satisfaction and loyalty in foodservice institutions. For example, $\mathrm{Ng}$ (2005) found that the elements of service quality were ranked second to food quality in affecting student satisfaction with foodservice facility. Service quality attributes includes appearance of employees, staff attentiveness, level of service, food items' knowledge and friendly treatment. Saglik et al. (2014) examined university students' perception of service quality and its impact on the students' satisfaction and their behavioral intentions. The findings of the study revealed that even though the students' perceptions of cleanliness factor among the dimensions of the service offered in the cafeteria were not very high, still they were higher than other service components, specifically, service and atmosphere. Therefore, it can be concluded that there is significant and positive relationship between service quality and student satisfaction. Bearing these factors in mind, customers' perceptions of service quality are crucial in the foodservice industry and an important predictor of customers' perceptions and behavior (Kwun, 2011).
On-campus foodservice operations 
IHR

34,1

\section{Price, value for money and menu options}

Customers' perception of quality and price are the two fundamental factors that govern the level of perceived value and customer satisfaction which ultimately influence customers' positive behavioral intentions (Joung et al., 2016; Kwun, 2011; Lim, 2010). Chen et al. (1994) described perceived price as the customer's acceptable and fair opinion of the service's average price in comparison to its competitors. Klassen et al. (2005) compared demand for foodservices with the capacity available at California State University and found that price is the most significant factor in selecting a foodservice service provider for students with limited budgets. Lim (2010) stated that customers are likely to return to a restaurant again if price is perceived to be fair. Contrarily, if they perceive that the price is unfair they will voice their displeasure and not return to use the service. This is even more likely among students that have limited budgets, and continually seek reasonable and affordable-priced meals. More recently, Othman et al. (2013) suggested that price is the first concern expressed by students regarding a university's foodservice, because students purchase meals on restricted funds. Also, they indicated that students prefer to purchase cheaper meals off campus if the on-campus facilities are too expensive. Nadzirah et al. (2013) proposed that the paid price should be appropriate for the quantity of food, so the students would believe they received value for the price paid, which in turn yield student satisfaction and dining frequency. Moreover, value for money with suitable portion sizes should be the focus of foodservice providers to achieve student satisfaction with on-campus foodservices and dining frequency. According to Joung et al. (2016), perceived value is a predictor of customer satisfaction, in that, the greater the perceptions of the value of the service, the greater customer satisfaction will be. Therefore, the evidence is clear that price and value for money interrelate with student satisfaction. Other attributes contributing to customer's dining experience and their wish to return are menu options and ambience (Joung et al., 2014). Wooten $e t$ al. (2018) found that menu variety and healthy options scored the lowest level of satisfaction on a survey completed by 325 students on a campus with dining facilities operated by one contract foodservice management company.

\section{Meal plans and dining habits}

There is sparse research about students' meal plans in higher education institutions. Over a decade ago, Gramling et al. (2005) stated that an institution can be effective in managing its student population by providing students with a variety of meal-plan options, a diverse food menu, pleasurable dining experiences and an abundance of food outlets. Gramling et al.'s study showed that most of the campus meal-plan holders are residential students age 17 to 22 years, and 59 percent of diners surveyed, disliked the meal plan and used it because they were compelled to, by virtue of the residential arrangement. The outcome of the findings of this study creates an arena for negative relationships between students and their institutions as well as the students' attitude toward their foodservice providers. In a study conducted by College \& University Consumer Trend (Williams, 2013), it was found that only one-third of 3,400 US college students who were surveyed, were satisfied with their meal plans. In total, 44 percent wished their campus had grocery stores where they could shop using their meal plan, 46 percent expressed their desire to purchase food and beverages from mobile food trucks, 69 percent bought food and beverages from an on-campus foodservice location once a week or more, 63 percent purchased food from off-campus restaurants at least once a week and 66 percent frequently explored new types of foods and flavors. The findings of the students' dining habits reported by the College \& University Consumer Trend Report (Williams, 2013) indicate that students have diverse needs and preferences and providing the right dining package will not only yield satisfaction but potentially impact recruitment numbers, retention rates and possibly alumni relations. 
From the literature review cited above, it is clear that while several studies have been published on both tangible and intangible aspects of foodservice operations that influence satisfaction levels of and loyalty toward on-campus dining, to our knowledge, no research on how HBCU students perceive on-campus foodservice operations can be found, leaving a gap in the body of knowledge on students' perception of on-campus foodservices, their satisfaction and dining frequency. Therefore, the purpose and focus of this study was to determine the students' perceptions of an on-campus foodservice from an HBCU perspective, specifically in relation to the quality of food, ambience, value, food and beverage options, and service, resulting satisfaction and dining frequencies.

\section{Hypothesis development}

Generally, students' perceptions of their on-campus foodservice experience reflect their overall satisfaction with their dining experiences (Ali and Ryu's, 2015; Hall, 2014; Othman et al., 2013). Considering students' perceptions can influence their satisfaction, which in turn could impact the institution's reputation, student enrollment, student retention and the marketability of the institution to future students, it is critical to examine the students' perceptions of the on-campus food and beverage options, service quality, quality of food, value for money and ambience in relationship to overall satisfaction. Accordingly, in the context of the HBCU students' perceptions, we hypothesized the following:

H1. Food and beverage options have a significant impact on students' overall satisfaction.

H2. Service quality has a significant impact on students' overall satisfaction.

H3. Quality of food has a significant impact on students' overall satisfaction.

H4. Value for money has a significant impact on students' overall satisfaction.

H5. Ambience has a significant impact on students' overall satisfaction.

In the context of services marketing, customer satisfaction is often viewed as a central determinant of customer retention. Kivela et al. (1999) suggested that a customer's post-dining decision on returning to a restaurant is the moment of final truth for the restaurateur. Moreover, Law et al. (2004) focused on the effect of waiting time and service dimensions on customer satisfaction and repurchasing behavior. Their results indicate that difference in waiting time and wait satisfaction respectively influences customer satisfaction, leading to customer's repurchasing frequency. Kivela et al. (2000) tried to relate dining satisfaction and return patronage and concluded that dining satisfaction appears to moderate the relationship between the dining experience and post-dining behavioral intentions in a relatively generalizable way. Moreover, Ali and Ryu (2015) also confirmed a significant impact of dining satisfaction on dining frequency in the context of on-campus dining facilities. Therefore, it is assumed that if students are satisfied with the on-campus foodservice providers, they are more likely to continue to purchase it and thus the following hypothesis is proposed:

H6. Students' overall satisfaction has a significant impact on their dining frequency (Figure 1).

\section{Methods}

\section{Sample and data collection}

The population for this study was all students at a private, co-ed, historically black university located in south of USA (student population is approximately 4,500), who have used the on-campus dining facilities. By employing purposive sampling, data collection took place on campus over a 3-day period. Purposive sampling is one of the most common forms of sampling in social science research and popular in service marketing 


\section{IHR \\ 34,1}

\section{0}

Figure 1.

Theoretical framework

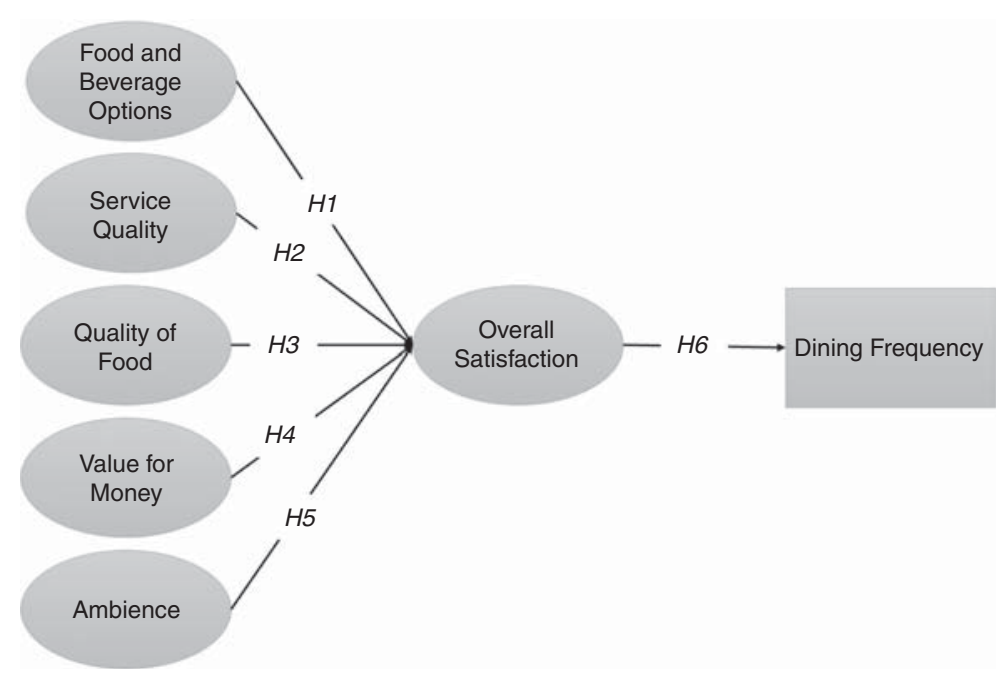

(Widing et al., 2003). Student research assistants administered the survey to respondents. Research assistants were required to complete the NIH Certification and participated in training over two one-hour sessions. Students equipped with clipboards, pencils and surveys conducted the data collection anywhere on campus they came across others. At the end of survey completion, respondents were offered fruit snacks as an incentive. The survey was offered only after confirming that the potential participant has used the dining facilities on campus. A total of 685 surveys were collected, and 664 were usable responses, reflecting 97 percent of collected surveys. This sample size fulfills the requirements of sample size considering the population of 4,500 with 5 percent margin of error and $95 \%$ confidence level.

\section{Survey instrument and construct measures}

The objective of this research is to determine the students' perceptions of the on-campus foodservice operations at the identified institution. The survey instrument, using a five-point Likert scale, was developed using Kim et al. (2004) and Hall (2014) surveys as the baseline. The survey was pilot-tested with 11 students majoring in hospitality management. Students then participated in a discussion of how the items were worded, what they understood from the items, and whether they were able to answer the items honestly, after which the instrument was restructured and realigned.

The instrument comprised of four sections. The first section of seven questions aimed at gaining demographic and behavioral data on the participants (gender, age group, classification, nationality, meal plan type and number of visits to the facility). The second section included five subsections. The first subsection comprised of five statements regarding the quality of food, adopted from both Kim et al. (2004) and Hall (2014). The second subsection had four statements about the ambience of the dining hall adopted from both Kim et al. (2004) and Hall (2014). The third subsection had two statements regarding value for money which were adopted from Hall (2014). The fourth subsection included three items regarding food and beverage options, adopted from Hall (2014). The final subsection comprised of nine statements regarding service quality, adopted from both Kim et al. (2004) and Hall (2014). Participants ranked statements along a Likert-type scale, where $1=$ strongly disagree, $3=$ neutral and $5=$ strongly agree. 
The third section of the survey comprised of three statements where participants ranked their overall satisfaction with the dining facility, service and experience, adopted from both Kim et al. (2004) and Hall (2014). These statements were on a five-point Likert-type scale where $1=$ very low, $3=$ neutral and $5=$ very high. The final section, entitled Any Other Comments, allowed participants to state their personal views.

Data analysis

The survey data were inputted to SurveyMonkey for processing and analysis. Frequencies, percentages and weighted averages were ascertained using this platform. Of the 664 responses, 52 percent were female, 86 percent were 23 years or below, 61 percent had been students at the institution for two years or less, 80 percent had a residential meal plan and 87 percent identified as African-American or black. Notably, only 26 percent indicated they used the facility for all three meals per day and 21 percent used it more than five days per week.

Partial least squares based structural equation modeling (PLS-SEM) was used to test the proposed structural model with SmartPLS 3.0. PLS-SEM was preferred as it well suits the characteristics of the investigation and the nature of the collected data (Hair et al., 2011). This choice was made first because of the explorative nature of the study. Second, as measures were developed with a Likert scale, data have a non-normal data distribution. PLS does not require any normality assumptions and handles non-normal distributions relatively well (Ali et al., 2018). PLS-SEM is also a suitable technique for the study on prediction and expanding the variance in key target constructs of a research model which contains levels of multi-dimensionality (Ali et al., 2018). Following the guidelines by Hair et al. (2011), we used bootstrapping with 5,000 sub-samples to estimate the $t$-values to assess the level of significance for path coefficients.

\section{Results}

\section{Measurement model}

The internal consistency reliability of construct items, convergent validity and discriminant validity were assessed (see Table I). All the item cross-loadings were significant and above the recommended level of 0.7 to their respective constructs (Hair et al., 2011). Furthermore, the composite reliability (CR) and average variance extracted (AVE) estimates were used to test the internal consistency reliability and convergent validity. The $\mathrm{CR}$ indices of each scale were all greater than the level of 0.70 recommended by Bagozzi (1980). Thus, the internal consistency reliability of the measurement items is confirmed. Also, AVE scores exceeded the cutoff of 0.50 recommended by Hair et al. (2011), which verifies the convergent validity of the measures. Lastly, the square root of the AVE value of each construct was greater than its correlations with any other construct, which demonstrates discriminant validity as shown in Table II. Moreover, discriminant validity was also validated by employing the HTMT approach. Overall the measures utilized have been shown to have adequate psychometric properties.

\section{Structural model}

To estimate the structural model, the collinearity among the constructs in the structural model was assessed. The variance inflation factor (VIF) value showed minimal collinearity in the structural model as all VIF values are below the common cutoff threshold of 5 to 10 . Next, the $R^{2}$ and the significance of the path coefficients were used for structural model evaluation. The results of $R^{2}$ value (for customer satisfaction: 0.836 ) indicate adequate explanatory power. An analysis of path coefficients and levels of significance show that all direct effects are significant.

Food and beverage options have a positively significant impact on student's overall satisfaction $(\beta=0.136, p<0.05)$. Service quality also has a positively significant impact on 
Quality of food $\alpha=0.877 ; C R=0.910 ; A V E=0.670 ;$ rho_A $A=0.882$

The food tastes delicious

2.340

2.400

The food is fresh

The food is healthy

Hot food is served at the right temperature

Cold food is served at the right temperature

Ambience $\alpha=0.895 ; C R=0.927 ; A V E=0.760 ;$ rho $\_A=0.898$

The decor is appropriate

The dining hall is clean

The seating is comfortable

The lighting is appropriate

Value for money $\alpha=0.785 ; C R=0.903 ; A V E=0.823 ;$ rho_ $A=0.787$

The portion size of the meal is appropriate

Items are reasonably priced

Food and beverage options $\alpha=0.896 ; C R=0.935 ; A V E=0.828$; $r h o \_A=0.903$

There is adequate variety of breakfast items

There is adequate variety of lunch items

There is adequate variety of dinner items

Service quality $\alpha=0.929 ; C R=0.941 ; A V E=0.640 ;$ rho_ $A=0.931$

Service staff are knowledgeable of menu items

Service staff are courteous

Service staff are professional

Service staff apply hygiene procedures while serving

Service staff work quickly

Convenience of operating hours during breakfast is appropriate

Convenience of operating hours during lunch is appropriate

Customer satisfaction $\alpha=0.902 ; C R=0.939 ; A V E=0.836 ;$ rho $\_A=0.902$

Rate your overall satisfaction with the dining facility

Table I.

Rate your overall satisfaction with the overall dining experience

student's overall satisfaction $(\beta=0.357, p<0.05)$. Similarly, quality of food has a positively significant impact on student's overall satisfaction $(\beta=0.324, p<0.05)$. Moreover, value for money has a positively significant impact on student's overall satisfaction $(\beta=0.159$, $p<0.05)$. Ambience has a positively significant impact on student's overall satisfaction $(\beta=0.136, p<0.05)$. Lastly, overall satisfaction has a positively significant impact on student's dining frequency $(\beta=0.121, p<0.05)$. As such, all the hypotheses are supported. Regarding model validation, the model estimation with PLS-SEM reveals a SRMR value of 0.058 , which confirms the overall fit of the PLS path model. Table III presents the values of all the path coefficients and corresponding $t$-values and $p$-values.

\section{Multi-group analysis}

The final step of the analysis examines the model across one variable, i.e. meal plan. For this variable, the entire data set was respondents with a residential meal plan $(n=527)$ and non-residential meal plan $(n=135)$ to determine the moderating effects of specified 


\begin{tabular}{|c|c|c|c|c|c|c|c|c|}
\hline & 1 & 2 & 3 & 4 & 5 & 6 & 7 & On-campus \\
\hline \multicolumn{8}{|l|}{ Fornell-Larcker criterion } & operations \\
\hline Food and beverage options & 0.592 & \multicolumn{6}{|l|}{0.910} & \multirow{6}{*}{23} \\
\hline Overall satisfaction & 0.598 & 0.620 & 0.914 & & & & & \\
\hline Quality of food & 0.683 & 0.646 & 0.694 & 0.819 & & & & \\
\hline Service quality & 0.706 & 0.646 & 0.707 & 0.670 & 0.800 & & & \\
\hline Value for money & 0.583 & 0.641 & 0.576 & 0.610 & 0.634 & \multirow{2}{*}{\multicolumn{2}{|c|}{$\begin{array}{l}0.907 \\
0.516\end{array}$}} & \\
\hline Dining frequency & 0.463 & 0.623 & 0.539 & 0.551 & 0.627 & & 1.000 & \\
\hline \multicolumn{9}{|c|}{ Heterotrait-monotrait ratio (HTMT) } \\
\hline \multicolumn{9}{|l|}{ Ambience } \\
\hline Overall satisfaction & 0.664 & 0.688 & & & & & & \\
\hline Quality of food & 0.775 & 0.728 & 0.777 & & & & & \\
\hline Service quality & 0.771 & 0.711 & 0.770 & 0.744 & & & & \\
\hline Value for money & 0.695 & 0.765 & 0.684 & 0.736 & 0.742 & & & \\
\hline Dining frequency & 0.529 & 0.731 & 0.675 & 0.668 & 0.701 & 0.631 & & \\
\hline \multicolumn{8}{|c|}{$\begin{array}{l}\text { Notes: Italic values represent square root of average variance extracted; Correlations of paired constructs are } \\
\text { on the off-diagonal. All squared correlations are significant at } p<0.05\end{array}$} & $\begin{array}{l}\text { Table II. } \\
\text { Discriminant validity }\end{array}$ \\
\hline
\end{tabular}

\begin{tabular}{llllll}
\hline Hypotheses & $\beta$ & $t$-value & $p$-values & Results \\
\hline H1: Food and beverage options $\rightarrow$ Overall satisfaction & 0.136 & 3.815 & 0.000 & Supported & \\
H2: Service quality $\rightarrow$ Overall satisfaction & 0.357 & 8.106 & 0.000 & Supported & \\
H3: Quality of food $\rightarrow$ Overall satisfaction & 0.324 & 7.592 & 0.000 & Supported & \\
H4: Value for money $\rightarrow$ Overall satisfaction & 0.159 & 1.9777 & 0.049 & Supported & \\
H5: Ambience $\rightarrow$ Overall satisfaction & 0.111 & 2.266 & 0.031 & Supported & Table III. \\
H6: Overall satisfaction $\rightarrow$ Dining frequency & 0.121 & 3.231 & 0.001 & Supported & Hypotheses testing \\
\hline
\end{tabular}

variable on the significant causal effects in the model. Permutation tests examined differences in the relationships among the constructs across both segments. All the three steps in permutation test were held (original correlation $>5$ percent quantile and $p$-values $>0.05$ ) true (Ali et al., 2018). Hence, it was established that the model results may differ across both the groups (respondents with a residential meal plan and respondents without a residential meal plan). The next step considered the differences in strength of the path coefficients for both the groups.

As per the findings in Table IV, while there were some minor differences in strengths of the relationships, no significant differences were found for the impact of food and

\begin{tabular}{|c|c|c|c|c|c|}
\hline \multirow[b]{2}{*}{ Hypotheses } & \multicolumn{2}{|c|}{ Residential meal plan } & \multicolumn{2}{|c|}{ Non-residential meal plan } & \\
\hline & $\beta$ & Sig. & $\beta$ & Sig. & \\
\hline H1: Food and beverage options $\rightarrow$ Overall satisfaction & 0.140 & 0.000 & 0.100 & 0.001 & \\
\hline H2: Service quality $\rightarrow$ Overall satisfaction & 0.344 & 0.000 & 0.348 & 0.020 & \\
\hline H3: Quality of food $\rightarrow$ Overall satisfaction & 0.338 & 0.000 & 0.2195 & 0.001 & \\
\hline H4: Value for money $\rightarrow$ Overall satisfaction & 0.042 & 0.061 & 0.1845 & 0.050 & \\
\hline H5: Ambience $\rightarrow$ Overall satisfaction & 0.119 & 0.050 & 0.143 & 0.001 & Table IV. \\
\hline H6: Overall satisfaction $\rightarrow$ Dining frequency & 0.101 & 0.001 & 0.113 & 0.000 & Multi-group analysis \\
\hline
\end{tabular}


IHR

34,1

beverage options, service quality, quality of food and ambience on overall satisfaction and the impact of overall satisfaction on dining frequency for both the groups (respondents with a residential meal plan and respondents without a residential meal plan). However, an interesting finding here is the significant difference for the impact of value for money on overall satisfaction. Respondents without a residential meal plan thought of the on-campus meal options as "Value for their money" and it had a significant impact on their overall satisfaction, whereas for respondents with a residential meal plan, they did not think of the on-campus meal options as "Value for their money" and it had a non-significant impact on their satisfaction. In terms of strengths of relationships, the impact of ambience, quality of food and food and beverage options on overall satisfaction was stronger for non-residential meal plan holders. Overall, it seems that respondents without a residential meal plan hold better perceptions of on-campus dining facilities compared to those with a residential meal plan.

\section{Conclusion and implications}

The purpose of this study was to determine the HBCU students' perceptions of an oncampus foodservice facility, specifically in relation to the operation attributes of quality of food, ambience, value, food and beverage options and service and how it impacts their dining frequency. Results indicate that the six hypotheses tested were supported. All service and operations attributes investigated have a positively significant impact on the overall satisfaction of students using the foodservice facility and that the overall satisfaction significantly impacts their dining frequency at the foodservice facility. Consequently, there is compelling evidence indicating negative perceptions of the foodservice facility based on the statistically significant relationship found between overall satisfaction and quality of food, ambience, value for money, food and beverage options and service quality. Therefore, any positive adjustments to these attributes will positively influence the overall satisfaction of the end users, the students, which will ultimately shape their favorable behavior. The results further support previous studies (Ali and Ryu, 2015; Lam and Heung, 1998; Yen-Soon et al., 2004; Joung et al., 2016) which indicated a positively significant relationship between student satisfaction and behavior and the various elements of the foodservice facility and operations that were examined. Additionally, it corroborates Williams' (2013) five trends that foodservice providers should adopt to yield customer satisfaction. As well, the research validates previous research (Chen et al., 1994; Joung et al., 2016; Kwun, 2011; Lim, 2010) which purported that perceived value, influenced by price and quality, inspires positive behavioral intentions. This would explain the difference indicated between the commuter and residential student groups on the perceived value, as they would be comparing the value to that of competitors off campus. Thus, the management of the facility should consider reviewing its opening hours, food and beverage options, ambience and the culture of the institution and its student body, as areas for improvement in its customer satisfaction efforts and increasing students' dining frequency.

This study is of grave importance because adverse perceptions and lack of student satisfaction with on-campus foodservice operations could negatively impact dining frequency of the students, risking the institution's reputation, student retention and the marketability of the institution to future students. As an $\mathrm{HBCU}$, the results from this research lends credence to Hall (2014) which indicated that cultural background is an influence in the perceptions and behavior of on-campus dining by residential students. Additionally, this study contributes to research in the field by showing the perceptions and behavior of students in an HBCU setting, filling the identified gap in the research. According to Nadzirah et al. (2013), customer behavior and satisfaction with the foodservice entity is impacted by their experience, real or perceived. Thus, the implications of this study are vital to the institution specifically and may have far-reaching influence at other HBCUs. 
As indicated by Joung et al. (2014), having the knowledge of how students perceive these service and operations attributes provides the on-campus foodservice facility with a competitive advantage and an opportunity to differentiate themselves. Foodservice providers and administration can therefore use the results of this study to examine and improve operations to meet the needs of their customers, the students. In so doing, the on-campus foodservice providers now have the potential to increase satisfaction with present students thus influencing dining frequencies. Additionally, there is the potential to affect the marketability of the institution and therefore influence the recruitment of new students.

\section{Limitations and suggestion for future research}

The major limitation to this study is generalization. Data for this study were collected at an HBCU in the Southern USA and may therefore not reflect the perceptions of students at other HBCUs in other parts of the USA. Subsequently, future research should include students at other HBCU campuses. As well, the study cannot be generalized to student bodies at predominantly white institutions (PWIs) due to the minimal representation of Caucasian respondents. Thus, future research could include student populations at PWIs. Even though this study looked into the impact of students' perception on their behavior related to on-campus food operations, future studies should also analyze if students' perception of foodservice plays in their decision to attend one institution vs another. Another interesting research idea will be to examine the role of negative perception of the on-campus foodservice operations on the institutional image.

\section{References}

Ali, F. and Ryu, K. (2015), "Bringing them back to spend more: student foodservice experiences to satisfy their taste buds", Young Consumers, Vol. 16 No. 2, pp. 235-248.

Ali, F., Rasoolimanesh, S.M., Sarstedt, M., Ringle, C.M. and Ryu, K. (2018), "An assessment of the use of partial least squares structural equation modeling (PLS-SEM) in hospitality research", International Journal of Contemporary Hospitality Management, Vol. 30 No. 1, pp. 514-538.

Andaleeb, S.S. and Caskey, A. (2007), "Satisfaction with food services: insights from a college cafeteria”, Journal of Foodservice Business Research, Vol. 10 No. 2, pp. 51-65.

Bagozzi, R.P. (1980), "Performance and satisfaction in an industrial sales force: an examination of their antecedents and simultaneity", Journal of Marketing, Vol. 44 No. 2, pp. 65-77.

Brown, M.C. II and Ricard, R.B. (2007), "The honorable past and uncertain future of the nation's HBCUs", Thought \& Action, Vol. 23 No. 2, pp. 117-130.

Chen, I.J., Gupta, A. and Rom, W. (1994), "A study of price and quality in service operations", International Journal of Service Industry Management, Vol. 5 No. 2, pp. 23-33.

Chickering, A.W. and Reisser, L. (1993), Education and Identity. The Jossey-Bass Higher and Adult Education Series, Jossey-Bass Publishers, San Francisco, CA.

Choi, E.K., Wilson, A. and Fowler, D. (2013), "Exploring customer experiential components and the conceptual framework of customer experience, customer satisfaction, and actual behavior", Journal of Foodservice Business Research, Vol. 16 No. 4, pp. 347-358.

Dollah, S.N., Mansor, N. and Mohamed, M. (2012), "Exploring the major determinants of student satisfaction on university cafeteria food services: a Malaysian case", Interdisciplinary Journal of Research in Business, Vol. 2 No. 7, pp. 62-73.

El-Said, O.A. and Fathy, E.A. (2015), "Assessing university students' satisfaction with on-campus cafeteria services", Tourism Management Perspectives, Vol. 16 No. 1, pp. 318-324.

Fletcher, C. (2014), "Should you attend a historically black college?", available at: www.campusex plorer.com/college-advice-tips/0F91182C/Should-You-Attend-a-Historically-Black-College/ (accessed January 21, 2019). 
IHR

34,1

Garg, A. (2014), "Mechanic clues vs. humanic clues: students' perception towards service quality of fast food restaurants in Taylor's University Campus”, Procedia-Social and Behavioral Sciences, Vol. 144 No. 1, pp. 164-175.

Gasman, M. (2013), "The changing face of historically black colleges and universities”, Graduate School of Education, University of Pennsylvania, Philadelphia, PA, available at: www.gse.upenn.edu/ pdf/cmsi/Changing_Face_HBCUs.pdf (accessed January 15, 2019).

Gramling, L., Byrd, R., Epps, L., Keith, D., Lick, R. and Tian, R. (2005), "Foodservice management and its impact on college operations: a business anthropological case study", Foodservice Research International, Vol. 16 Nos 1-2, pp. 15-43.

Hair, J.F., Ringle, C.M. and Sarstedt, M. (2011), "PLS-SEM: indeed a silver bullet”, Journal of Marketing Theory and Practice, Vol. 19 No. 2, pp. 139-152.

Hall, J.K. (2014), "Student satisfaction regarding meal experience at the residential dining halls of the University of Pretoria", doctoral dissertation, University of Pretoria, Pretoria.

Heung, V.C., Wong, M.Y. and Qu, H. (2000), "Airport-restaurant service quality in Hong Kong: an application of SERVQUAL", Cornell Hotel and Restaurant Administration Quarterly, Vol. 41 No. 3, pp. 86-96.

Hu, H., Kandampully, J. and Juwaheer, T.D. (2009), "Relationships and impacts of service quality, perceived value, customer satisfaction, and image: an empirical study", The Service Industries Journal, Vol. 29 No. 2, pp. 111-125.

Imram, N. (1999), "The role of visual cues in consumer perception and acceptance of a food product", Nutrition \& Food Science, Vol. 99 No. 5, pp. 224-230.

IPEDS (2016), "Integrated post-secondary post data system IPEDS", National Center for Educational Statistics, Washington, DC, available at: http://nces.ed.gov/ipeds/ (accessed January 15, 2019).

Joung, H.W., Choi, E.K. and Wang, E. (2016), "Effects of perceived quality and perceived value of campus foodservice on customer satisfaction: moderating role of gender", Journal of Quality Assurance in Hospitality \& Tourism, Vol. 17 No. 2, pp. 101-113.

Joung, H.W., Lee, D.S., Kim, H.S. and Huffman, L. (2014), "Evaluation of the on-campus dining services using importance-performance analysis", Journal of Foodservice Business Research, Vol. 17 No. 2 , pp. 136-146.

Kim, H.J., McCahon, C. and Miller, J. (2004), "Assessing service quality in Korean casualdining restaurants using DINESERV”, Journal of Foodservice Business Research, Vol. 6 No. 1, pp. 67-86.

Kim, W.G., Ng, C.Y.N. and Kim, Y.S. (2009), "Influence of institutional DINESERV on customer satisfaction, return intention, and word-of-mouth", International Journal of Hospitality Management, Vol. 28 No. 1, pp. 10-17.

Kivela, J., Inbakaran, R. and Reece, J. (1999), "Consumer research in the restaurant environment, Part 1: a conceptual model of dining satisfaction and return patronage", International Journal of Contemporary Hospitality Management, Vol. 11 No. 5, pp. 205-222.

Kivela, J., Inbakaran, R. and Reece, J. (2000), “Consumer research in the restaurant environment, part III: data collection and interpretation of findings", International Journal of Contemporary Hospitality Management, Vol. 12 No. 1, pp. 13-20.

Klassen, K.J., Trybus, E. and Kumar, A. (2005), "Planning food services for a campus setting", International Journal of Hospitality Management, Vol. 24 No. 4, pp. 579-609.

Kwun, D.J.W. (2011), "Effects of campus foodservice attributes on perceived value, satisfaction, and consumer attitude: a gender-difference approach”, International Journal of Hospitality Management, Vol. 30 No. 2, pp. 252-261.

Lam, T.C. and Heung, V.C. (1998), "University foodservice in Hong Kong: a study of consumers' expectations and satisfaction levels", Journal of College \& University Foodservice, Vol. 3 No. 4, pp. 3-12.

Law, A.K., Hui, Y.V. and Zhao, X. (2004), "Modeling repurchase frequency and customer satisfaction for fast food outlets", International Journal of Quality \& Reliability Management, Vol. 21 No. 5, pp. 545-563. 
Lim, H. (2010), "Understanding America customer perceptions on Japanese food and services in the U.S", doctoral dissertation, University of Las Vegas, Las Vegas, NV.

Nadzirah, S., Karim, A.S., Ghazali, H. and Othman, M. (2013), "University foodservice: an overview of factors influencing the customers' dining choice”, International Food Research Journal, Vol. 20 No. 3, pp. 1459-1468.

$\mathrm{Ng}$, Y. (2005), "Study of the impact of customer satisfaction on intention to return and return intention, and word-of-mouth endorsement in university dining operations", published master thesis, Oklahoma State University, Stillwater, OK.

Nichols, A.H. and Evans-Bell, D. (2017), "A look at black student success: identifying top- and bottomperforming institutions", The Education Trust, Washington, DC.

Othman, M., Salehuddin, N., Karim, M.S.A. and Ghazali, H. (2013), "Customers' satisfaction towards institutional foodservices: an insight into universities in the Klang Valley", Journal of Business and Policy Research, Vol. 8 No. 2, pp. 1-15.

Oz, S.N., Ihtiyar, A., Ahmad, F.S. and Ali, F. (2016), "A conceptual framework to explain the impact of visitors' previous experiences on customer satisfaction", Journal of Global Business Insights, Vol. 1 No. 1, pp. 38-49.

Palmer, R. and Gasman, M. (2008), "It takes a village to raise a child': the role of social capital in promoting academic success for African American men at a Black college", Journal of College Student Development, Vol. 49 No. 1, pp. 52-70.

Parasuraman, A., Berry, L.L. and Zeithaml, V.A. (1991), "Understanding customer expectations of service", Sloan Management Review, Vol. 32 No. 3, pp. 39-48.

Parasuraman, A., Zeithaml, V.A. and Berry, L.L. (1988), "Servqual: a multiple-item scale for measuring consumer perceptions", Journal of Retailing, Vol. 64 No. 1, pp. 12-40.

Parasuraman, A., Zeithaml, V.A. and Berry, L.L. (1985), "A conceptual model of service quality and its implications for future research", Journal of Marketing, Vol. 49 No. 4, pp. 41-50.

Raajpoot, N.A. (2002), "TANGSERV: a multiple item scale for measuring tangible quality in foodservice industry", Journal of Foodservice Business Research, Vol. 5 No. 2, pp. 109-127.

Ryu, K. and Jang, S. (2008), "DINESCAPE: a scale for customers' perception of dining environments", Journal of Foodservice Business Research, Vol. 11 No. 1, pp. 2-22.

Saglik, E., Gulluce, A., Kaya, U. and Ozhan, C. (2014), "Service quality and customer satisfaction relationship: a research in Erzurum Ataturk university refectory", American International Journal of Contemporary Research, Vol. 4 No. 1, pp. 100-117.

Stevens, P., Knutson, B. and Patton, M. (1995), "DINESERV: a tool for measuring service quality in restaurants", The Cornell Hotel and Restaurant Administration Quarterly, Vol. 36 No. 2, pp. 5-60.

Technomic (2011), "College \& university consumer trend report", March 15, available at: www.technomic. com/Pressroom/Releases/dynRelease_Detail.php?rUID=110 (accessed January 15, 2019).

Tudin, R., Kim, S.T.C. and Ayupp, K. (2010), "Hostel tenants' perception toward cafes located in the campus”, Working Paper Series No. 1003, University of Malaysia, Sarawak, Kota Samarahan.

US Department of Education, National Center for Education Statistics (Ed.) (2016), “Table 303.40: total fall enrollment in degree-granting postsecondary institutions, by attendance status, sex, and age: selected years, 1970 through 2026", Digest of Education Statistics, 2016 ed., Washington, DC, pp. 1-970.

Widing, R.E., Sheth, J.N., Pulendran, S., Mittal, B. and Newman, B.I. (2003), Customer Behaviour: Consumer Behaviour and Beyond, Cengage Learning, Melbourne.

Williams, L. (2013), "The meal plan: how savvy administrators make strategic decisions about the whole campus dining experience - because meal planning isn't just about the food", University Business, Hosuton, TX, p. 42.

Wooten, R., Lambert, L.G. and Joung, H.W. (2018), "Evaluation of students' satisfaction with three all-you-can-eat university dining facilities", Journal of Foodservice Business Research, Vol. 21 No. 5, pp. 539-552. 
Yen-Soon, Y.S., Moreo, P.J. and Yeh, R.J. (2004), “Customers' satisfaction factors regarding university food court service", Journal of Foodservice Business Research, Vol. 7 No. 4, pp. 97-110.

Yllmaz, E. (2008), “Toplam Kalite Yönetimi ve insan merkezli kütüphanecilik”, ÜNAK, Vol. 6 No. 1, pp. 12-14.

\section{Further reading}

Berry, L.L. (1988), "SERVQUAL: a multiple-item scale for measuring consumer perceptions of service quality", Journal of Retailing, Vol. 64 No. 1, pp. 12-40.

Bethune-Cookman University (2017), "Bethune-Cookman University Fact Book, 2016-17", Bethune-Cookman University, Daytona Beach, FL.

Hair, J.F. Jr, Hult, G.T.M., Ringle, C. and Sarstedt, M. (2016), A Primer on Partial Least Squares Structural Equation Modeling (PLS-SEM), Sage Publications, Thousand Oaks, CA.

Kim, W.G., Han, J.S. and Lee, E. (2001), "Effects of relationship marketing on repeat purchase and word of mouth", Journal of Hospitality \& Tourism Research, Vol. 25 No. 3, pp. 272-288.

Kim, Y.S., Moreo, P.J. and Yeh, R.J. (2006), “Customers' satisfaction factors regarding university food court service”, Journal of Foodservice Business Research, Vol. 7 No. 4, pp. 97-110.

National Center for Higher Education Management Systems Information Center (2019), "Fast facts: historically black colleges and universities", available at: https://nces.ed.gov/fastfacts/display. asp?id $=667$

Olorunniwo, F., Hsu, M.K. and Udo, G.J. (2006), "Service quality, customer satisfaction, and behavioral intentions in the service factory", Journal of Services Marketing, Vol. 20 No. 1, pp. 59-72.

\section{Corresponding author}

Faizan Ali can be contacted at: faizanali@sar.usf.edu

For instructions on how to order reprints of this article, please visit our website: 